\title{
The Language of Schooling: A Challenge to Subject Learning
}

\author{
Eli Moe
}

\section{Introduction}

This article focuses on the importance of language as a tool for acquiring knowledge in traditional content subjects at school. In history, mathematics and other subjects, students learn through reading texts, listening and talking to teachers and peers, and answering questions, tasks and assignments in writing. A low level of language competence, therefore, would influence students' subject learning.

This article builds on findings drawn from the project Language descriptors for migrant and minority students' success in compulsory education, which was sponsored by the European Centre for Modern Languages (ЕCML) in Graz in 2012 and 2013 (and on materials collected in connection with an ECML think tank on the language of schooling in September 2016 (ECML 2016).

The project Language descriptors for immigrant students' success in compulsory education (ECML 2012-2015) had two main aims. The first was to indicate the minimum language standard, in terms of levels on the Common European Framework of Reference (CEFR), that students at the age of $12 / 13$ and 15/16 need to have in order to experience success in history or civics and mathematics in compulsory education. The project group also developed a tool, a set of language descriptors for listening, reading, speaking and writing, to support teachers and students and make them aware of the language challenges students face when learning academic subjects. 
Much of the research carried out in this field has focused on describing the language of schooling and on determining language requirements associated with subjects and specific age groups. Few researchers, so far, have looked at challenges related to preparing teachers and schools for organising and teaching the language of schooling. In 2016, the ECML set up a think tank called Whole school approaches to the language/s of schooling (ECML 2016). The main activity of the think tank was to collect information from educational experts across Europe on how to focus on the language of schooling at a school level. The ECML, with a moderation team of three persons, collected information through an online questionnaire and a workshop with experts in Graz in September 2016.

\section{Aim and motivation}

The article's aim is twofold: to introduce the term language of schooling and to present some of the findings derived from a questionnaire focusing on whole-school approaches to the language of schooling. The questionnaire findings are included in order to explore what needs to be done in order to enable subject teachers to take the language of their subjects into account when teaching this subject.

The term language of schooling needs to be introduced since it is relatively new, and since it represents a challenge to all subject teachers. In particular, this is of concern for those who teach according to a curriculum in which aims for basic skills and subject topics are integrated. In Norway, for instance, this is the case. Aims for reading, speaking and writing, are inherent in the competence aims in traditional subjects like geography and mathematics. Many subject teachers may not have reflected on the language challenge represented in their subject and the fact that knowledge is acquired and expressed through language. However, they are aware that, in order to learn, students have to read textbooks or articles and listen to what teachers say. The language of schooling is a topic rarely addressed in subject teacher education, in in-service courses or when planning lessons.

On the one hand, there is the way the language of schooling has been characterised by some researchers and what this may mean in terms of age. On the other, there is the question of how to build on research findings, and go one step further and explore how to teach subjects like history and science with the language of schooling in mind. 
In the second part of the article, we present some findings from a questionnaire, which was distributed online by the ECML in spring 2016. The questionnaire focused on whole-school approaches to the language of schooling. The language of schooling is one of three priority topics in the ECML's 2016-2019 program, and the questionnaire marked the first activity of a new Languages of schooling think tank (ECML 2016). The motivation for focusing on the materials collected in this questionnaire is to show what the respondents think needs to be done in a school context, as well as some of the challenges subject and language teachers are faced with when teaching subjects and language at the same time. To shed light on these issues, we have focused on four of the questions in the questionnaire. Two of them were open-ended and therefore gave the respondents an opportunity to elaborate when giving their answers.

\section{Background}

Since the late 1970s, Jim Cummins has been focusing on bilingual education and equal opportunities for all students. Cummins' main message has been that the language used in school is often a challenge for students with an immigrant background, and that there is no one-to-one relationship between mastery of everyday language and of the language used in a school context. Cummins (1979) defines two different types of language: Basic interpersonal communication skills, BICs, and Cognitive academic language proficiency, CALP. BICS refers to the language used in everyday contexts, which often develops rapidly in a second language. CALP, on the other hand, is the language that students meet in a subject context at school. According to Cummins, the language used at school is in many ways a barrier blocking 'vulnerable' learners' efforts to reach their potential. Discourse functions like describe, compare, evaluate, analyse etc. are examples of CALP functions students have to master. When teachers are not aware of the inherent language challenges represented in subjects like science, history, mathematics etc., learning may become very problematic for students with an immigrant background, as well as for other 'vulnerable' groups of students.

During the last decade, the language used in a school context has received renewed attention from educational experts, researchers and teachers. Educational experts agree that, in order to learn and acquire knowledge, students need language (Beacco et al. 2010, Schleppegrell 
2006). Many have stated that the language used in a school context differs from everyday language (Cummins 1970, Schleppegrell 2001). Teachers have always known intuitively that, from around grade four and onwards, the language setting students start to work with and in becomes slightly more academic than that which they experienced during their first years in school. Most students are ready for this change, while a few have problems coping with demands related to, for instance, increasingly abstract vocabulary and greater text complexity, as well as their ability to express their knowledge (orally and in writing) and to show understanding in different subjects. There is a growing awareness among researchers and teachers that learning a subject implies more than learning facts. In order to acquire knowledge in traditional non-language subjects, it is also necessary to master a language; it is this that makes learning possible. According to Beacco et al. (2010), all knowledge building in the school context involves working with language. Students have to be able to read and understand what is presented in textbooks, to understand what teachers and peers are saying, to exchange information and ideas in group work, and to hand in written assignments and perform on school tests. In short, they have to use the language as a means both to show their understanding, and to develop their skills and their knowledge. Newspaper articles and public discussions show that many immigrant students and other 'vulnerable learners' have problems acquiring knowledge in many subjects due to language problems. They struggle to reach their potential in school subjects because their level of language proficiency is too low (Christensen 2014a, 2014b; Gudbrandsen 2014). Unless we focus on this issue specifically, the gap between those who are able to learn and master the language of textbooks, tasks and teacher talk, and those who are not, will keep on growing throughout the school years.

\section{The language of schooling}

The earliest use of the term language of schooling that the author has been able to find, is in the 2001 article by Mary Schleppegrell entitled "The linguistic features of the language of schooling." According to Schleppegrell, she cannot guarantee that the term was not used earlier. She says she did not take it from any other source, but wanted to use a term that was different from "academic language" to indicate that it is in the context of schooling more generally that children encounter language 
used in new ways (personal communication). From 2005, the Council of Europe's Language Policy Division has used the term language(s) of schooling actively and supported projects and activities related to this. In 2009, the council set up an electronic resource platform dedicated to the language(s) of schooling, including articles, studies and political documents, which could support teachers and schools and ensure plurilingual and intercultural education for all. Since 2010, teachers, researchers and educational experts in several countries have used the term.

Language(s) of schooling refers to the language all students have to relate to and communicate in during their education, both first and second language users.

\subsection{Characteristics}

Mary Schleppegrell (2006) stresses that the linguistic challenges in academic language are connected with the way knowledge is conveyed and organised, as well as the authoritative way meaning is expressed. Academic language is information dense and full of abstractions. This makes it difficult for many students to grasp the content of texts. Second language learners, in particular, are challenged since the use of dictionaries seldom helps. Using examples from O'Halloran (2003), Schleppegrell $(2006,55)$ shows that, in mathematics, students have to cope with three different languages, more or less simultaneously. They have to link the teacher's oral explanations with the symbolic language of mathematics. In addition, the written language they meet in textbooks is different from the language the teacher speaks. Another example is that, when students write at school, they are expected to structure their texts in specific ways. Requirements vary from subject to subject and, in some cases, from teacher to teacher. A report from an experiment in physics would be structured in a different way than a literary analysis or a social science text discussing the consequences of use and misuse of drugs. Students have to learn such genre requirements for each subject separately. The last point Schleppegrell raises is that good textbook authors express themselves efficiently, accurately and with authority, using relevant vocabulary. They also have to express themselves as experts in order to make readers respect their knowledge. According to Schleppegrell, academic texts are full of passive constructions, the style is neutral and objective, and the focus is on subject matter and not the author himself. It is there- 
fore of vital importance that subject teachers provide their students with tasks that promote learning and help them develop the academic language the subject requires them to master (Schleppegrell \& O'Halloran 2011).

Beacco (2010), Vollmer (2010), Pieper (2011) and Linneweber-Lammerskitten (2012) discuss the language students need to cope with in order to meet academic challenges at the end of compulsory education, at the age of $15-16 .{ }^{1}$ The specific linguistic and semiotic competences students ought to have at this point include strategic competence, discourse competence and formal (linguistic) competence. Strategic competence implies that students have the ability to plan, execute, evaluate and correct the linguistic activities they are involved in in school. Discourse competence means being able to understand and cope with the different types of discourse that students encounter in school subjects. Textbooks, lectures, reports, articles, news items and documentaries are examples of types of discourse students may meet in different school subjects. Formal competence is, according to the authors mentioned above, the ability to formulate sentences and texts with correct spelling, morphology and syntax, as well as to use different discourse functions, such as to argue, classify, compare, explain, define, illustrate etc. All of these functions, and more, are typically used in most school subjects.

The outlines above primarily focus on the academic language used at school. Thürmann, Vollmer and Pieper (2010) provide a wider perspective on what characterises the language used in a school context. According to these authors, the language of schooling includes all language used in school. Figure 1 shows the different varieties of school language.

Figure 1: Language of schooling (Thürmann et al. 2010, 8)

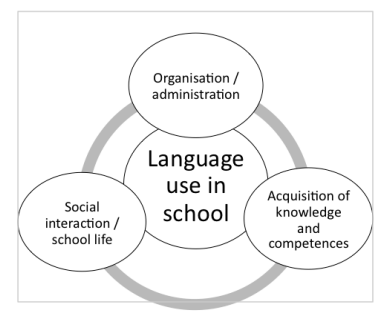

1 In most European countries, compulsory education is the period from when the students are 5-6 until they are 15-16 years old (European Commission/Eurydice, 2015) 
The language of schooling includes all language used in connection with knowledge building and the development of skills in all subjects, both in language classes and in traditional subjects, such as science and history. In addition, students have to cope with the more formal or administrative language, which they encounter in rules and regulations in a school context. Finally yet importantly, students have to be able to interact and communicate fluently in social settings at school. According to Thürmann, this means that students have to develop and master different language varieties in order to succeed socially and academically. These varieties are not totally separated from each other, but are more of a combination of informal language uses, content language and academic language. It is a great challenge to ensure that vulnerable students' school results mirror their potential and abilities, and not their lack of language proficiency.

\subsection{Age}

All students face increasing language challenges as they move upwards in the educational system. Some students find these challenges particularly difficult to overcome. In this respect, students with an immigrant background and those with a socially- and economically-disadvantaged background are vulnerable groups. Many large-scale assessment studies have identified this trend (Yang Hansen et al. 2012; Caro et al. 2012; Mullis et al. 2012).

Several studies have indicated specific levels of language competence that students at a certain age ought to have in order to do well at school. Table 1 gives an overview ${ }^{2}$ of six studies relating age to language requirements in terms of levels of the Common European Framework of reference for Languages, the CEFR (2001).

Beacco (2010), Vollmer (2010), Linneweber-Lammerskitten (2011) and Pieper (2012) have produced four documents, which are available at the Council of Europe's Languages of schooling platform. The documents follow the same structure and have the same aim: to offer support to those creating a curriculum for a subject "which explicitly takes into account the discursive and linguistic dimensions of this school subject" (Beacco 2010). All four authors refer to the general language requirements all students in compulsory education need to meet when they are 15-16 years

2 The list may not be extensive, but as far as the author knows, these are the only studies (pre-2017) that relate the language of schooling to age and the Common European Framework of Reference for Languages (CEFR), 2001. 
old. Second-language learners face particular challenges since they, in addition to learning a new language, also have to acquire knowledge in a language that is not their mother tongue. Beacco, Vollmer, LinneweberLammerskitten and Pieper have studied curricula, competence goals, relevant discourse functions, exam papers and tests that students at the end of compulsory education work both with and toward in the following subjects: history (Beacco), science (Vollmer), mathematics (LinneweberLammeskitten) and literary studies (Pieper). Their claim is that students at this age should have a language competence mirroring the level $\mathrm{B}_{2}$ of the CEFR in order to be successful in school.

Table 1: Overview of some studies relating language of schooling to age

\begin{tabular}{|c|c|c|c|c|}
\hline Author & $\begin{array}{l}\text { Basis for } \\
\text { determining } \\
\text { required CEFR level }\end{array}$ & $\begin{array}{l}\text { Subject in } \\
\text { focus }\end{array}$ & Age group & $\begin{array}{l}\text { Required } \\
\text { language } \\
\text { level }\end{array}$ \\
\hline Beacco 2010 & $\begin{array}{l}\text { Investigation of } \\
\text { curriculum goals, } \\
\text { exam papers }\end{array}$ & History & $15-16$ & B2 \\
\hline Vollmer 2010 & $\begin{array}{l}\text { Investigation of } \\
\text { curriculum goals, } \\
\text { exam papers }\end{array}$ & Sciences & $15-16$ & B2 \\
\hline $\begin{array}{l}\text { Linneweber- } \\
\text { Lammerskitten } \\
2011\end{array}$ & $\begin{array}{l}\text { Investigation of } \\
\text { curriculum goals, } \\
\text { exam papers }\end{array}$ & Mathematics & $15-16$ & B2 \\
\hline Pieper 2012 & $\begin{array}{l}\text { Investigation of } \\
\text { curriculum goals, } \\
\text { exam papers }\end{array}$ & $\begin{array}{l}\text { Literary } \\
\text { studies }\end{array}$ & $15-16$ & B2 \\
\hline $\begin{array}{l}\text { Moe, Härmälä, } \\
\text { Kristmanson, } \\
\text { Pascoal, } \\
\text { Ramoniené } 2015\end{array}$ & $\begin{array}{l}\text { Questionnaire } \\
\text { answered by } \\
\text { teachers from } 21 \\
\text { countries }\end{array}$ & $\begin{array}{l}\text { History/ } \\
\text { social } \\
\text { science } \\
\text { Mathematics }\end{array}$ & $\begin{array}{l}12-13 \\
15-16\end{array}$ & $\begin{array}{l}\mathrm{B} 1 \\
\mathrm{~B} 2\end{array}$ \\
\hline $\begin{array}{l}\text { Moe, Blair, } \\
\text { Sundet (in } \\
\text { production) }\end{array}$ & Study of textbooks & $\begin{array}{l}\text { Social } \\
\text { science }\end{array}$ & $\begin{array}{l}9-10 \\
12-13 \\
15-16\end{array}$ & $\begin{array}{l}\mathrm{A} 2(+) \\
\mathrm{B} 1(+) \\
\mathrm{B} 2(+)\end{array}$ \\
\hline
\end{tabular}


In the project Language descriptors for migrant and minority students' success in compulsory education, Moe et al. (2015) developed and validated CEFR-linked language descriptors for the subjects history/social science and mathematics for two age groups: $12 / 13$ and 15/16 year old students. This included descriptors for listening, reading, speaking and writing for the CEFR levels A2, B1 and B2. Then, 102 mathematics teachers and 127 history/social science teachers from more than 20 European countries assessed whether students at $12 / 13$ and $15 / 16$ needed to be able to do what the descriptors indicated. The overall results revealed that, according to these teachers, 12-13 year old students need a B1 competence both in history/social science and in mathematics in listening, reading, speaking and writing in order to reach competence goals in the subjects. The findings also suggested that 15-16 year old students ought to have a B2 competence in the same subjects and skills (Moe, Härmälä \& Kristmanson 2015). These findings are in line with those of Beacco (2010) and Linneweber-Lammerskitten (2011).

In another study, Moe, Blair and Sundet (Blair \& Sundet 2016) analysed the reading competence, in terms of CEFR levels, that students in the fourth, seventh and tenth grades in Norway were expected to have in order to read and understand Norwegian textbooks in social science. The language of six textbooks in social science was analysed, using 'the Dutch grid', a method suggested by Alderson et al. to support test developers and ensure a valid linkage of texts and tasks to the CEFR (Alderson et al. 2006). The findings of this study suggest that fourth-grade students in Norway (age 9) need to have at least an A2 reading competence in order to be able to read fourth grade textbooks. Seventh graders need a $\mathrm{B} 1$ or $\mathrm{B}_{1}+$ competence, while tenth graders need at least a $\mathrm{B}_{2}$ reading competence. The findings regarding Norwegian seventh (12/13) and tenth graders $(15 / 16)$ are in line with the findings of Moe, Härmälä \& Kristmanson (2015) mentioned above.

\section{ECML questionnaire on whole-school approaches to the language of schooling}

Researchers have tried to define what the language of schooling is, and have stressed and explained the importance of mastering this language. Relatively few, to date, have investigated how to teach the language of schooling. One of the reasons for this is probably the fact that many stake- 
holders think that this would require organisational amendments at their school. Not all teachers of mathematics, science or history are language teachers and vice versa. However, in many countries, educational experts agree that learning a subject also involves learning the language of this subject (Schleppegrell 2006, Thürmann et al. 2010). Because of this, requirements for basic skills, such as for instance reading and writing, have been incorporated in competence goals of all subjects in a number of countries. This means that competence goals mention not only the topics students should work with, but also how they are expected to perform and display their subject knowledge.

In order to find out more about what schools and teachers need if they are to develop a strategy for teaching the language of schooling, the ECML organised a think tank focusing on the language of schooling (ECML 2016). The think tank focused on whole-school approaches to the language of schooling. A moderation team, led by Marisa Cavalli from the ECML, was in charge of developing and launching an online questionnaire and organising a two-day think tank workshop in Graz, Austria, in September 2016. The questionnaire included 24 questions, 11 of which required elaborate answers from the respondents. A link to the questionnaire was sent out to educational experts and national contact points in many European countries. The questionnaire produced 107 complete answers from respondents in 33 countries. Most of these were teachers from all sectors, from pre-primary to upper-secondary schools. Approximately one fifth were teacher trainers and almost one fifth were academic researchers. In addition, there were responses from parents.

In this article, we focus on a few of the findings the questionnaire produced and on the answers to four of the questions, numbers 7, 12, 15 and 19 (ECML 2016). The motivation for choosing these questions is twofold: the answers say something about who should be involved in a project like this, and what would be necessary in order to embark on such a journey. We consider that the answers shed light on the question of why teachers seem to be hesitant about getting involved in teaching the language of schooling. In addition, they offer ideas about possible ways to proceed. The four questions that will be examined more closely are the following:

Question 7: Which of the following people should be responsible for implementing a whole-school approach to the language of schooling? 
Question 12: In what way can whole-school cooperation projects for support in the language(s) of schooling best be facilitated?

Question 15: Do language teachers have a specific role to play in such projects? How can they support subject teachers?

Question 19: Outline the steps you think a school has to follow in order to be able to implement this kind of cooperation (these could include organisational aspects such as role definitions, space and time available).

Questions 7 and 12 are multiple-choice questions, while questions 15 and 19 are open-ended. The responses to the questionnaire have been analysed by Marisa Cavalli and Margit Huber from the ECML, as well as by Gunter Abuja, Austria, and Eli Moe, Norway, who were members of the ECML moderation team. The full questionnaire is included at the end of this article.

\subsection{Question 7: Which of the following people should be responsible for} implementing a whole-school approach to the language of schooling?

The respondents could give several answers to this question. The spread of answers given indicates that the respondents think that several stakeholders ought to be involved in a project focusing on the language of schooling. $26 \%$ of the answers say that the whole teaching staff should be involved in such a project. Many also think that parents need to take part. The answers indicate that since the idea of teaching the language of schooling would be something new, as many as possible would need to be involved and informed about what goes on in order to ensure a successful outcome. (See figure 2).

On the one hand, the answers indicate that all stakeholders need to take part in such a project. On the other, the questionnaire produced elaborated feedback on what role the head teacher would have to play. He or she would have to lead the whole institution throughout the project. One of the respondents expressed the following thoughts on the head teacher's role as institutional leader: 
The head teacher needs to have a vision of the importance of languages of schooling, and s/he needs to be able to communicate this understanding to the staff, so that the school is able to develop a school-wide approach to language development. S/he needs to be willing to support teachers' training in the area, and allow them to bring in members of the different language communities to support students' learning.

Figure 2: Who should be responsible for a language of schooling project?

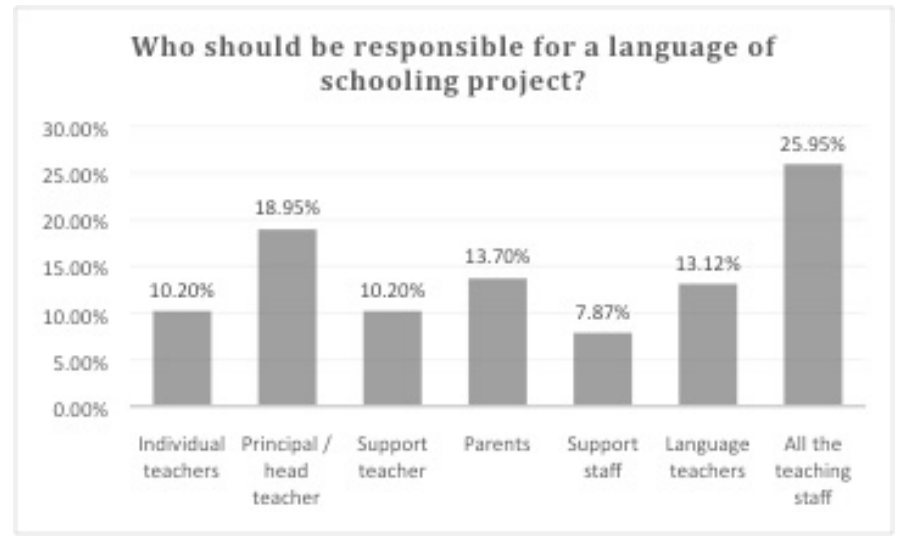

The head teacher would also have to be a constructive leader organising the project in a way that would make progress and learning possible. One of the experts answered as follows:

The head teacher's role should be to guide and motivate the teachers through this challenge and to provide opportunities for dialog, training and support. Education is dynamic and changing at an alarming rate; head teachers need to spear point the efforts and facilitate the development of the language of schooling by fostering communication between language and subject teachers.

Last, but not least, the head teacher would have to feel responsibility for getting the staff on board the project. One of the respondents put it as follows: 
The role of the head teacher is crucial, since he/she should point out to the teachers how important it is for them to get a better insight into the role of language in their subject. He/she should stimulate and make it possible for the teachers to learn more about this and set a goal for the subject teams to develop methods for teaching the language of their subjects.

5.2. Question 12: In what way can whole-school cooperation projects for support in the language(s) of schooling best be facilitated?

The respondents could choose to answer up to three of the options for this question.

Figure 3: What would be beneficial when engaging in a language of schooling project?

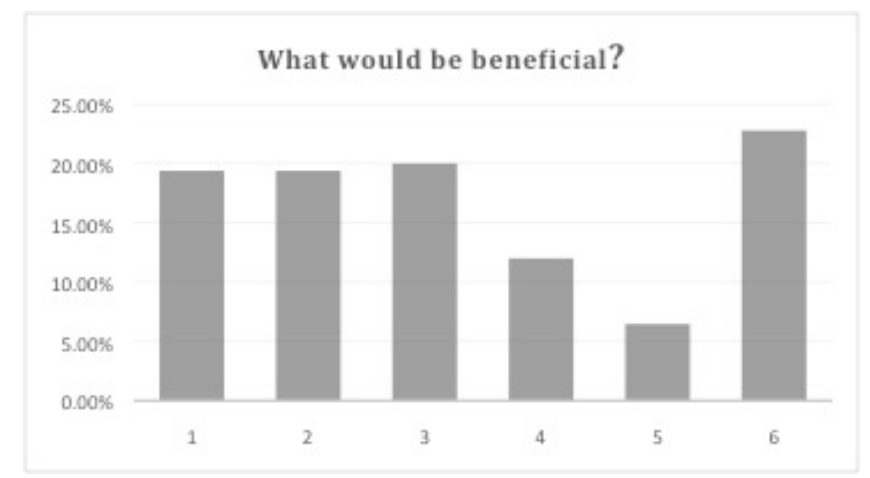

1. Examples of concrete school projects which have involved the cooperation of different teachers (language/subject) and/or other players (head teachers, parents, learners) in relation to the language of schooling

2. A step-by-step guide based on real school experiences of how to move towards cooperation involving all players

3. The development, piloting and evaluation of teaching materials to be used in classrooms with other subject teachers

4. Examples of school language policies or strategies

5. Testimonies from head teachers who have successfully initiated and supported this kind of cooperation

6. Training modules for teachers and head teachers

The answers indicate that the teachers would like to have support and support materials in a language of schooling project. As shown in Figure 3, most answers are distributed evenly between four of the options, numbers 1, 2, 3 and 6 . The answers indicate that the respondents 
think they would like to learn from other people's experiences if they were to participate in a language of schooling project. This could either be done by being informed about similar projects $(20 \%)$ or by attending training modules for teachers and head teachers (23\%). They could also follow a detailed guide developed with such a project in mind (20\%). In addition, respondents think that they would learn from taking part in a project where they could develop their own teaching materials and pilot it in their own classes (20\%).

\subsection{Question 15: Do language teachers have a specific role to play in this} cooperation? How can they support subject teachers?

The respondents differ slightly in their views on the role language teachers and subject teachers ought to have in a whole school project of this type. On one hand, several of the respondents stress that language teachers have an important role to play in a project concerned with the language of schooling. Many say that the language teachers should make subject teachers aware of the role language plays in knowledge building. On the other hand, a number of respondents point out that subject teachers must be in charge of teaching the content of specific subjects. They also say that language teachers may be able to focus on genres/discourse functions, but that there is a danger of superficial teaching if content is not taken seriously. In their view, the language teachers' role should be limited to monitoring and assisting subject teachers, and support from language teachers should be request-based.

Other respondents stress that a whole school project is a joint project in which the entire staff participates, which means that all teachers are language teachers. Furthermore, according to the respondents, language teachers can support subject teachers by making language progress visible to them (and their students), encouraging them to rethink the aims of their subjects and reflect on the scaffolding of students. Respondents claim that cooperation between subject teachers and language teachers would make subject- and language-learning experiences interesting and meaningful, and probably tap into students' interests and resources. They also say that cooperation between subject and language teachers should include issues like lesson planning, preparation of teaching materials, team teaching, discussion and reflection on student assessment. 
The respondents seem to think that, since language teachers probably are more aware of issues related to the language of schooling, they must be active in raising awareness and discussing learning from a multitude of angles, at least in the initial phase. Still, the main lesson to be learned from the responses is that the entire staff should be included and be responsible in such a project. In order to help students achieve their potential, different stakeholders must cooperate.

5.4. Question 19: Outline the steps you think a school has to follow in order to be able to implement this kind of cooperation.

Several of the respondents suggested a type of classical project planning in which the first step would be to formulate a vision, then prepare a project plan and recruit key personnel on whom the project would rely. Much of the work in the initial phase would be to raise awareness among the staff and other stakeholders of the rationale of the project. In addition, those in charge of the project should ensure that the vision, major steps and outcomes are transparent to those involved. As one of the respondents said: "Communicate, communicate, communicate!"

The next step would be, as far as possible, to plan the project in detail. This would involve practical issues with regard to the organisation of staff, as well as ideas about teaching methods and materials.

Many projects benefit from cooperation with other schools and institutions. If resources allow, teacher trainers and researchers could function as supervisors, either during the whole project or for a short period. Since this would be an innovative project, it would be of vital importance to have a constructive approach and learn from examples of good practice.

\subsection{Some reservations}

Since research on the language of schooling is limited, especially research related to teaching methods and practices, some of the respondents feel there is little evidence supporting the idea of setting up a whole-school project. Such a project would be time consuming, and schools would have to allocate many resources to it. Many of the points the respondents raise are related to teacher training and research on the language of schooling. If teacher training focused on teaching the language of schooling, both subject and language teachers would be more aware of language compe- 
tence as an important variable in subject learning. In addition, teacher trainers and students would start to reflect on methods for teaching the language of schooling. Stakeholders would like reassurance regarding the outcomes before embarking on a large project. According to feedback collected, head teachers and subject teachers would need some sort of evidence supporting their involvement in such a project.

\section{Language of schooling: concluding remarks}

\subsection{Subject and language learning: the current situation}

Educational authorities in many countries recognise the role language plays in knowledge building by integrating language requirements in subject curricula and competence goals. How the schools and teachers in different countries teach subject and language warrants a study of its own. Many of the respondents to the ECML questionnaire came from France, Spain and Switzerland, which may indicate that the authorities and teachers are particularly interested in this topic in these countries. In Norway, basic skills underpin competence goals in all grades and subjects in compulsory education. In 2012, The Norwegian Directorate for Education and Training introduced a framework for basic skills, which is to underpin all curricula for all grades in basic education in Norway (2012). According to this framework, there are five skills considered basic: oral skills, reading, writing, digital skills and numeracy. For each skill, five competence levels are described. These skills are considered fundamental to learning in all subjects and they are therefore inherent in competence goals in all subjects in Norwegian basic education. The competence goals are expressed in terms of a range of tasks students should be able to do. The basic skills are considered a means by which students can express their understanding and knowledge in all subjects. At the base of this framework is a recognition of the role language plays in knowledge building. At the time of writing, in 2017, the framework is not validated, and we do not know whether the levels of this framework are perceived and used in the same way within and across subjects and grades. Perhaps the Norwegian framework for basic skills could become a more practical tool for teachers if small-scale studies were set up, the aim of which would be to describe in detail students' basic skills in different subjects and grades. In the next round, the descriptions of skills could be mapped in relation to different levels of the framework for ba- 
sic skills. Presumably, useful discussions would arise from such studies, which would feed back to teachers, and fuel creative and innovative work among stakeholders.

\subsection{Organisational amendments}

According to the responses to the ECML questionnaire, individual teachers should not be the only ones responsible for teaching the language of schooling. The responses to question 7 indicated quite clearly that many stakeholders ought to be involved in a language of schooling project. In answer to question 15, the respondents indicated that subject teachers and language teachers should cooperate in teaching the language of schooling.

The cooperation between subject teachers and language teachers stands in contrast to traditional teaching, where normally one teacher is responsible for what goes on in classes that he or she is teaching. If different stakeholders are to be involved in teaching the language of schooling, this will, without doubt, have implications for the way the timetable is organised and for the allocation of rooms and offices in a school. Staff must have time to plan teaching periods and lessons, and rooms where this can be done.

The EсML questionnaire focused on whole-school approaches to the language of schooling. It is possible to organise a language of schooling project on a smaller scale, involving, for instance, one class or the classes of one grade in a school. However, whether such a project is carried out on a small or a large scale, good planning and organisation are vital for its success and meaningfulness for those involved.

In contrast to CLIL teaching, ${ }^{3}$ teaching the language of schooling involves working with the main language used in most subjects in a school. In CLIL, the same teacher often teaches a foreign language and a traditional 'knowledge' subject, for instance history, in the same class. The students will then learn history in English or French (or another foreign language). CLIL projects are often voluntary, driven by individual teachers' interest and enthusiasm, and such projects often require few organisational amendments. Teaching the language of schooling, on the other

3 CLIL is an abbreviation for Content and Language Integrated Learning, a teaching method aiming to combine content learning and language learning; for instance, Norwegian pupils learning math in English or French. 
hand, would in many cases involve a great deal of organisation. In many countries, teachers teach one or two specific subjects. A teacher of physics will not be a language teacher and vice versa. For these teachers to cooperate, organisational amendments are necessary that would involve not only teachers, but also people from the administration, who would have to consider timetables and room allocation. In some countries, one teacher is responsible for teaching most (or all) subjects in one class in primary school. This is the case, for instance, in the Nordic countries. In such cases, it would be easier to set up smaller language of schooling projects, which would not require many resources to organise.

\subsection{Implications for teaching and teachers}

In order to develop knowledge and understanding of a subject, students need to focus not only on learning facts, but also on working in and with the subject-specific language. They have to learn subject-specific vocabulary and style, as well as ways of structuring texts and formulating ideas.

A consequence of this is that teachers are responsible for developing students' knowledge and basic skills in their subjects by making language and knowledge accessible to them. In order to do so, the teacher(s) must have a good grasp of important knowledge issues, as well as a clear view of the language requirements implied. Teachers have to be able to analyse the subject language required at particular educational stages, as well as how this develops through the grades. With such a background, teachers must provide their students with tasks, scaffolding and models of good practice that help them to develop their knowledge reservoir and basic language skills in the subject. An emphasis on the language required to participate in subject classes enables teachers to set objectives that relate not only to the acquisition of content-related information, but also to the language functions necessary to negotiate meaning in that content area. According to Sherris (2008), the establishment of specific content and language objectives is a prerequisite for lesson planning in subject classes.

To illustrate the potential role of language in, for example, mathematics, let us consider an example from the mathematics classroom. If students are asked to read a table and communicate the main information included in the table, teachers need to equip their students with the linguistic tools necessary to perform this task (e.g. "This table tells me that $32 \%$ of students in Norwegian schools never go skiing"; "I can see in this 
table that $16 \%$ of girls prefer volleyball"). An awareness of the language required to express certain ideas reminds subject teachers to provide language models for learners to follow.

In history, teachers may want students to read primary source documents in order to extract various points of view on the same historical event. Since this is not only a content-related task, but also a linguistic one, teachers could show their students examples of different ways of expressing points of view. Moreover, they could teach reading strategies in order to facilitate the extraction of main ideas from a text. In addition, the prior knowledge that language functions related to comparing and contrasting would facilitate the achievement of this task would remind teachers to provide examples of ways to communicate comparisons (e.g. "From the point of many Norwegians, the German invasion in 1940 was seen as a provocation and a serious threat to Norwegian independence. However, from the perspective of some Norwegians, cooperation with the Germans would provide alliance to a powerful nation, which could yield financial advantages."). One can see from this example that certain words, phrases and transitional terms would be useful to learners in order to enable them to achieve the curricular outcomes. Mindfulness of such linguistic scaffolding gives teachers a way to see themselves not simply as subject teachers, but also as contributors to their students' language development.

The language of schooling could be taught in two main ways in traditional subject classes. Either subject teachers take the responsibility for teaching subject content and subject language; or subject teachers cooperate with other teachers who could guide and support them in providing students' with access to subject-specific language and setting goals for subject language development. According to the respondents of the ECML questionnaire, subject teachers and language teachers ought to cooperate since few teachers teach both traditional subjects like mathematics/history, as well as languages.

Researchers have studied the language of schooling in relation to specific factors such as characteristic features, discourse functions and age. What is lacking are studies focusing on how subject teachers work with language issues in the subject classroom. It is equally important that teacher-training addresses this topic and that data from research on 
teaching practices can feed back into new teaching methods and ideas regarding the way in which the language of schooling is or could be taught.

\section{References}

Alderson, J.C., N. Figueras, H. Kuijper, G. Nold, S. Takala, and C. Tardieu. 2006. "Analysing Tests of Reading and Listening in Relation to the Common European Framework of Reference: The Experience of The Dutch CEFr Construct Project.” Language Assessment Quarterly 3 (1):3-20.

Beacco, J.C., D. Coste, P.H. van de Ven, and H. Vollmer. 2010. "Language and School Subjects: Linguistic Dimensions of Knowledge Building in School Curricula." Strasbourg: Council of Europe, http://www.coe. int $/ \mathrm{t} / \mathrm{dg}_{4} /$ linguistic/langeduc/BoxD2-OtherSub_en.asp\#s2 (accessed 29 January, 2017).

Beacco, J.C. 2010. "Items for a Description of Linguistic Competence in the Language of Schooling necessary for Learning/teaching History (end of compulsory education): an Approach with Reference Points." Strasbourg: Council of Europe, Language Policy Division, https:// www.coe.int/t/dg4/linguistic/Source/Source2010_ForumGeneva/1_ LIS-History2010_en.pdf (accessed 29 January, 2017).

Blair, B. and K.T. Sundet (2016). "Social Science Reading Constructs and the CEFR Reading Level of Textbooks." Paper presented at the 13th annual conference of Ea LTA in Valencia, Spain., May 2016.

Caro, D.H. and D. Cortés. 2012. "Measuring Family Socioeconomic Status: An Illustration using Data from PI L L 2006 ." In Issues and Methodologies in Large-Scale Assessments. IER I Monograph Series Volume 5:9-33. Educational Testing Service and International Association for the Evaluation of Educational Achievement.

Christensen, R. 2014a. "Mange av elevene forstår ikke norsk." Bergens Tidende 28 May:8-9.

Christensen, R. 2014b. "Det er hyklersk å droppe språkkrav." Bergens Tidende 3 June:12.

Council of Europe. 2001. Common European Framework of Reference for Languages: Learning, Teaching, Assessment. Cambridge: Cambridge University Press. 
Cummins, J. 1979. "Cognitive/academic Language Proficiency, Linguistic Interdependence, the Optimum Age Question and Some Other Matters." Working Papers on Bilingualism 19:121-29.

ECML 2012-2015. Language Skills for Successful Subject Learning, http:// www.ecml.at/ECML-Programme/Programme2012-2015/LanguageDescriptors/tabid/180o/Default.aspx (accessed 29 January, 2017).

ECML 2016. Think Tanks Within the ECML 5th Medium-term Programme: Languages at the Heart of Learning, http://www.ecml.at/ECML-Programme/Thinktanks/tabid/1913/language/en-GB/Default.aspx (accessed 29 January, 2017).

Gudbrandsen, F. 2014. "Norsk først." Bergens Tidende 28 May:8.

Linneweber-Lammerskitten, H. 2012. "Items for a Description of Linguistic Competence in the Language of Schooling Necessary for Learning/teaching Mathematics (at the end of compulsory education). An Approach with Reference Points." Strasbourg: Language Policy Unit, Directorate of Education, DGIL. Council of Europe, https://www.coe.int/t/dg4/linguistic/Source/Source2010_ForumGeneva/4_LIS-Mathematics2012_EN.pdf (accessed January 29 2017)

Moe, E., M. Härmälä, P.L. Kristmanson, J. Pascoal, and M. Ramoniené. 2015. Language Skills for Successful Subject Learning. Strasbourg: Council of Europe Publishing.

Moe, E., M. Härmälä, and P.L. Kristmanson. 2015. "Learning Subject Matter in a Second Language: A CEFR-based Tool to Support Immigrant and Migrant Students." In Language Assessment for Multilingualism: Proceedings of the ALTE Paris Conference April 2014 (Studies in Language Testing 44), edited by Docherty, C. and F. Barker, 13253. Cambridge: UgLes/Cambridge University Press.

Mullis, I.V.S., M.O. Martin, P. Foy, and A. Arora. 2012. TIMSS 2011 International Results in Mathematics. Boston: Timss and Pirls International Study Center, Lynch School of Education, Boston College.

Norwegian Directorate for Education and Training. 2012. Rammeverk for grunnleggende ferdigheter, https://www.udir.no/laring-og-trivsel/ lareplanverket/grunnleggende-ferdigheter/rammeverk-for-grunnleggende-ferdigheter/ (accessed 29 January, 2017).

O'Halloran, K.L. 2003. "Educational Implications of Mathematics as a Multisemiotic Discourse." In Educational perspectives on Mathematics as Semiosis: From Thinking to Interpreting to Knowing, edited by 
M. Anderson, A. Saenz-Ludlow, S. Zellweger and V.V. Cifarelli, 185214. Brooklyn, NY/Ottawa, Ontario: Legas.

Pieper, I. 2011. "Items for a Description of Linguistic Competence in the Language of Schooling necessary for Learning/teaching Literature (end of compulsory education). An Approach with Reference Points." Strasbourg: Council of Europe, Language Policy Division, http:// www.coe.int/t/dg4/linguistic/Source/Source2010_ForumGeneva/1_ LIS-Literature2 011_EN.pdf (accessed 29 January, 2017).

Schleppegrell, M.J. and O'Halloran, K.L. 2011. “Teaching Academic Language in L2 Secondary Settings.” Annual Review of Applied Linguistics 31:3-18.

Schleppegrell, M.J. 2006. "The Challenges of Academic Language in School Subjects.” In Språket och kunskapen: att lära på sitt andraspråk $i$ skola och högskola, edited by I. Lindberg and K. Sandwall, 47-69. Göteborg, Sweden: Göteborgs universitet, Institutet för svenska som andraspråk.

Schleppegrell, M.J. 2001. Linguistic Features of the Language of Schooling. Linguistics and Education 12 (4):432-59.

Sherris, A. 2008 . Integrated Content and Language Instruction. Washington, DC: Centre for Applied Linguistics (CAL).

Thürmann, E., Vollmer, H. and I. Pieper. 2010. "Language(s) of Schooling: Focusing on Vulnerable Learners." Document prepared for the Policy Forum: The right of learners to quality and equity in education - The role of linguistic and intercultural competences, Geneva, Switzerland, 2-4 November 2010. Strasbourg: Council of Europe, Language Policy Division, http://www.coe.int/t/dg4/linguistic/Source/ Source2010_ForumGeneva/2-VulnerLLearnersThurm_EN.pdf (accessed 29 January 2017).

Vollmer, H.J. 2010. "Items for a Description of Linguistic Competence in the Language of Schooling necessary for Learning/teaching Sciences (at the end of compulsory education). An Approach with Reference Points." Strasbourg: Council of Europe, Language Policy Division, https://www.coe.int/t/dg4/linguistic/Source/Source2010_Forum Geneva/1-LIS-sciences2 010_EN.pdf (accessed 29 January, 2017).

Yang Hansen, K. and I. Munck. 2012. "Exploring the Measurement Profiles of Socioeconomic Background Indicators and their Differences in Reading Achievement: A Two-level Latent Class Analysis." In Is- 
sues and Methodologies in Large-Scale Assessments. IER I Monograph Series, 5:49-77. Educational Testing Service and International Association for the Evaluation of Educational Achievement.

Appendix: Languages of schooling Think tank questionnaire (spring 2016) Question 1 In which country do you work?

Question 2 Your role (in relation to the language/s of schooling) (you may tick more than one box).
1. Parent
2. Trainee teacher
3. Teacher of the language(s) of schooling
4. Teacher of modern languages
5. Teacher of classical languages
6. Subject teacher (please specify below)
7. Head teacher
8. Teacher trainer
9. Academic researcher
10. Consultant
11. School inspector
12. Policy maker
13. Other (please specify below)

Question 3 The educational stage in which you are involved (you may tick more than one box):
1. Pre-primary education (ISCED o)
2. Primary education or first stage of basic education (ISCED 1)
3. Lower secondary or second stage of basic education (ISCED 2)
4. (Upper) secondary education (ISCED 3)

Question 4 In comparison with other educational priorities in your country, this particular topic is considered:
1. A priority
2. Important
3. Quite useful
4. Marginal
5. I don't know

Question 5 How do schools ensure that children gain full access to education when their first language is other than the language of schooling?

1. Helping them become proficient in the language of schooling

2. Encouraging the use of their first language

3. Restricting the use of their first language 
Question 6 Learners are helped to become proficient in the language of schooling by:

1. Withdrawal from mainstream class for support in the language of schooling

2. Teaching the language of schooling before admittance in mainstream classes

3. Short duration withdrawal or in-class support for language of schooling support teacher

4. Including first language in curriculum delivery

5. Encouraging first language use in classroom to develop language awareness

Question 7 Which of the following people should be responsible for implementing a whole-school approach to the language of schooling?

1. Individual teacher

2. Principal / head teacher

3. Support teacher

4. Parents

5. Support staff

6. Language teachers

7. All the teaching staff

Question 8 Where parents do not speak the language of schooling their role in children's language education

1. - is unhelpful

2. - is limited

3 - can be harnessed through their first language as support for curriculum learning

Question 9 Has your educational system already started to implement some forms of whole-school cooperation for the language of schooling?

1. Yes

2. Partially

3. No

4. I don't know

Question 10 School projects which underline and explicitly address the language dimension in learning/teaching are

1. common practice

2. a practice in a few schools

3. a rare practice

4. a very rare practice

5. I don't know 
Question 11 In your context, have the following staff members received/are they receiving specific training in this area? (The respondents answer Yes, No or I don't know for each of the following)

1. Teachers of the language of schooling

2. Teachers of Modern languages

3. Teachers of classical languages

4. Subject

5. Head teachers

6. Trainee teachers

Question 12 Whole-school cooperation for support in the language(s) of schooling can be best facilitated by:

1. examples of concrete school projects which have involved the cooperation of different teachers (language/subject) and/or other players (head teachers, parents, learners) in relation to the language of schooling

2. a step-by-step guide based on real school experiences of how to move towards cooperation involving all players

3. the development, piloting and evaluation of teaching materials to be used in classrooms with other subject teachers

4. examples of school language policies or strategies

5. testimonies from head teachers who have successfully initiated and supported this kind of cooperation

6. training modules for teachers and head teachers

Question 13 Please explain why the topic of the language of schooling is or is not a priority in your country.

Question 14 What difficulties or resistance do you foresee in the idea of wholeschool cooperation in this area?

Question 15 Do language teachers have a specific role to play in this cooperation? How can they support subject teachers?

Question 16 What are the resources the teachers can draw on if they want to support different language groups in the understanding of the language of schooling?

Question 17 What could the role of the head teacher be?

Question 18 What kind of contribution can parents make and how will this be beneficial both to the parents themselves and to their children? 
Question 19 Outline the steps you think a school has to follow in order to be able to implement this kind of cooperation. (These could include organizational aspects such as role definitions, space and time available.)

Question 20 Do you have models of successful school cooperation of this kind in your country that you could share with us?

Question 21 To what extent do you think it is important that each school develops and makes public its language policy or strategy? Should the aspect of whole-school cooperation be emphasised?

Question 22 Could you indicate any other aspects of whole-school cooperation in the language of schooling not so far addressed by this consultation? 